ISSN 0258-7122 (Print), 2408-8293 (Online)

Bangladesh J. Agril. Res. 41(2): 365-376, June 2016

\title{
STUDY ON COMBINING ABILITY AND HETEROSIS FOR EARLINESS AND SHORT STATURED PLANT IN MAIZE
}

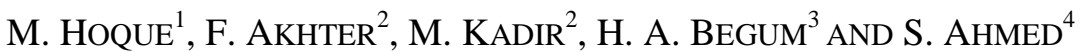

\begin{abstract}
An experiment was carried out in $6 \times 6$ diallel crosses for combining ability analysis for grain yield, maturity and growth parameters in maize. Analysis of variance for combining ability showed that mean square value due to GCA \& SCA were highly significant for all characters except SCA in days to tasseling and days to maturity indicated that all but two traits were governed by both additive and non-additive gene action. Variances due to GCA were much higher in magnitude than SCA indicated additive gene effects were much more important for all characters except cob length, thousand grain weight and ear height. The Parent $\mathrm{P}_{5}$ was the best general combiner for yield and most of the yield contributing characters. The Parent $\mathrm{P}_{1} \& \mathrm{P}_{2}$ were best general combiner for both dwarf and earliness. The crosses showing significant SCA effects for yield involving average $\mathrm{x}$ average, average $\mathrm{x}$ low and low $\mathrm{x}$ low general combining parents. The crosses $\mathrm{P}_{3} \mathrm{xP}_{6} \& \mathrm{P}_{4} \mathrm{xP}_{5}$ showed either significantly or numerically higher heterosis than checks BHM-5, BHM7 \& BHM-9 for yield.
\end{abstract}

Keywords: Maize, GCA, SCA and heterosis.

\section{Introduction}

Maize is one of the important cereal crops in our country. The maize area and production is increasing gradually and the crop is being popular among the farmers. It is well established that hybrid maize has more yield potential than composite or synthetic varieties. Due to yield advantages and other agronomic characters growers are very much interested to cultivate hybrid maize. But maximum seeds of the hybrid maize varieties are imported from foreign countries. The imported hybrid maize is very costly and farmers are not getting seed timely. For this reason, Plant breeding division of BARI is trying to fulfill this constrain. The nature and magnitude of gene action is an important factor in developing an effective breeding program. Combining ability analysis is useful to assess the potential inbred lines and also helps in identifying the nature of gene action involved in various quantitative characters. This information is helpful to plant breeders for formulating hybrid breeding program. Therefore, the present

${ }^{1}$ Plant Breeding Division, Bangladesh Agricultural Research Institute (BARI), Gazipur1701, ${ }^{2}$ Regional Agricultural Research Station, BARI, Jamalpur, ${ }^{3}$ Bangladesh Agricultural Development Corporation (Tuber Crop), Kashimpur, Gazipur, ${ }^{4}$ Plant Breeding Division, BARI, Gazipur, Bangladesh. 
investigation with $6 \times 6$ diallel cross was undertaken for isolating superior inbred lines and better combining parents for suitable hybrids.

\section{Materials and Method}

The experiment was conducted at RARS, Jamalpur during rabi 2012-13. Six inbred lines of maize were mated in a diallel fashion excluding the reciprocals. The resulting $15 \mathrm{~F}_{1} \mathrm{~s}$ were grown in alpha lattice design with three replications. Each plot consisted of two rows of $5 \mathrm{~m}$ long. The spacing between row to row was $60 \mathrm{~cm}$ and plant to plant was $20 \mathrm{~cm}$. One plant per hill was maintained. Fertilizers were applied @ 250, 120,120 40, 5 and $1 \mathrm{~kg} / \mathrm{ha}$ of $\mathrm{N}, \mathrm{P}_{2} \mathrm{O}_{5}, \mathrm{~K}_{2} \mathrm{O}, \mathrm{S}, \mathrm{Zn}$ and Boron, respectively.

Irrigation and other intercultural operations were done as and when necessary. Ten randomly selected plants from each plot were used for recording data of plant and ear height. Other data were collected by considering all the plants in a plot. Grain yield kg/plot was converted into grain yield t/ha. General combining ability (GCA) and specific combining ability (SCA) were estimated by following Griffing's method II, model IV. Percent heterosis was calculated by the formula as heterosis $(\%)=\left[\left(\mathrm{F}_{1}-\mathrm{CV}\right) / \mathrm{CV}\right] \mathrm{X} 100$. Where, $\mathrm{F}_{1}$ and $\mathrm{CV}$ represented the mean performance of hybrid and standard check variety. The estimated heterosis was tested according to Singh and Singh (1994).

\section{Results and Discussion}

\section{Analysis of variance}

Analysis of variance for combining ability showed that mean square values due to GCA \& SCA were highly significant for all characters except SCA in days to tasseling and days to maturity (Tables 1a and $1 \mathrm{~b}$ ). It indicated that all but above mentioned two traits were governed by both additive and non-additive gene action. Similar findings in maize were reported by Aguiar et al. (2004), Bhatnagar et al. (2004) and Abdel-Moneam et al. (2009). The additive gene action played a major role in controlling the character days to tasseling and days to maturity because of non-significant SCA of these characters. Kadir (2010) also observed non-significant SCA variance for some characters in maize.Variances due to GCA were much higher in magnitude than SCA indicated additive gene effect were much more important for all characters except cob length, thousand grain weight and ear height. This indicated predominance of additive gene action for all the characters except cob length, thousand grain weight and ear height seemed to be controlled by non additive gene action. Vacaro et al. (2002) and Uddin et al. (2006) also reported that mean sum of square for GCA effects was greater than that for SCA effects for some characters which indicating the predominance of additive effects. 
Table 1a. Mean squares due to general and specific combining ability on yield and yield components of maize.

\begin{tabular}{lcccccccc}
\hline \multicolumn{1}{c}{ Sources } & d.f & Yield (t/ha) & Cob length & Cob girth & No. of rows/ ear & No. of grains/ row & TGW (g) \\
\hline Rep & 2 & 0.28 & 0.01 & 0.17 & 0.07 & 5.43 & 21.51 \\
Crosses & 14 & $6.69^{* *}$ & $7.08^{* *}$ & $6.71^{* *}$ & $14.67 * *$ & $34.44^{* *}$ & $3479.19^{* *}$ \\
GCA & 5 & $7.79^{* *}$ & $5.58^{* *}$ & $13.19^{* *}$ & $34.43^{* *}$ & $60.04 * *$ & $3355.07 * *$ \\
SCA & 9 & $6.08^{* *}$ & $7.92^{* *}$ & $3.11^{* *}$ & $3.70^{* *}$ & $20.22^{* *}$ & $3548.15^{* *}$ \\
Error & 28 & 0.37 & 0.35 & 0.26 & 0.22 & 1.09 & 74.62 \\
\hline GCA/SCA & 0.56 & 1.28 & 0.71 & 4.24 & 9.31 & 2.97 & 0.95 \\
\hline
\end{tabular}

** indicate significant at $1 \%$ level; $\mathrm{TGW}=$ Thousand grain weight.

Table 1b. Mean squares due to general and specific combining ability on maturity and growth parameters of maize

\begin{tabular}{l|c|c|c|c|c|c}
\hline \multicolumn{1}{c|}{ Sources } & d.f & $\begin{array}{c}\text { Days to } \\
\text { tasseling }\end{array}$ & $\begin{array}{c}\text { Days to } \\
\text { silking }\end{array}$ & $\begin{array}{c}\text { Days to } \\
\text { maturity }\end{array}$ & $\begin{array}{c}\text { Plant height } \\
(\mathrm{cm})\end{array}$ & $\begin{array}{c}\text { Ear height } \\
(\mathrm{cm})\end{array}$ \\
\hline Rep & 2 & 1.76 & 2.96 & 28.80 & 16.80 & 31.67 \\
Crosses & 14 & $9.09^{* *}$ & $8.12^{* *}$ & $18.61^{*}$ & $852.29^{* *}$ & $233.14^{* *}$ \\
GCA & 5 & $14.39^{* *}$ & $12.29^{* *}$ & $31.37^{*}$ & $713.30^{* *}$ & $118.77^{* *}$ \\
SCA & 9 & $6.14 \mathrm{~ns}$ & $5.80^{* *}$ & $11.52 \mathrm{~ns}$ & $929.50^{* *}$ & $296.69^{* *}$ \\
Error & 28 & 3.21 & 0.91 & 7.97 & 21.59 & 22.17 \\
\hline GCA/SCA & 0.56 & 2.34 & 2.12 & 2.72 & 2.16 & 0.40 \\
\hline
\end{tabular}

*,** indicate significant at $5 \%$ and $1 \%$ level, respectively, ns= non-significant.

Table 2a. Mean performance of crosses for yield and yield components

\begin{tabular}{|c|c|c|c|c|c|c|}
\hline Cross & $\begin{array}{l}\text { Yield } \\
\text { (t/ha) }\end{array}$ & Cob length & $\begin{array}{l}\text { Cob } \\
\text { girth }\end{array}$ & \begin{tabular}{|c|} 
No. of \\
rows/ ear
\end{tabular} & $\begin{array}{c}\text { No. of } \\
\text { grains/ row }\end{array}$ & TGW (g) \\
\hline $\mathrm{P}_{1} \mathrm{XP}_{2}$ & 9.27 & 14.84 & 13.86 & 11.13 & 27.70 & 323.53 \\
\hline $\mathrm{P}_{1} \mathrm{XP}_{3}$ & 10.17 & 16.88 & 14.54 & 13.17 & 29.07 & 341.29 \\
\hline $\mathrm{P}_{1} \mathrm{XP}_{4}$ & 8.74 & 13.85 & 14.13 & 14.85 & 26.68 & 285.08 \\
\hline $\mathrm{P}_{1} \mathrm{XP}_{5}$ & 11.08 & 14.73 & 16.57 & 16.81 & 31.81 & 302.42 \\
\hline $\mathrm{P}_{1} \mathrm{XP}_{6}$ & 7.46 & 13.79 & 13.92 & 14.06 & 26.10 & 275.76 \\
\hline $\mathrm{P}_{2} \mathrm{XP}_{3}$ & 6.46 & 11.69 & 10.74 & 9.81 & 19.78 & 272.06 \\
\hline $\mathrm{P}_{2} \mathrm{XP}_{4}$ & 9.01 & 15.51 & 13.97 & 13.88 & 25.42 & 314.39 \\
\hline $\mathrm{P}_{2} \mathrm{XP}_{5}$ & 9.94 & 15.94 & 14.69 & 14.32 & 29.73 & 279.14 \\
\hline $\mathrm{P}_{2} \mathrm{XP}_{6}$ & 10.34 & 16.56 & 14.25 & 14.02 & 25.21 & 333.78 \\
\hline $\mathrm{P}_{3} \mathrm{XP}_{4}$ & 10.78 & 16.95 & 14.27 & 13.85 & 28.45 & 330.83 \\
\hline $\mathrm{P}_{3} \mathrm{XP}_{5}$ & 11.07 & 16.70 & 14.55 & 17.31 & 28.51 & 317.39 \\
\hline $\mathrm{P}_{3} \mathrm{XP}_{6}$ & 11.53 & 16.41 & 15.32 & 14.14 & 28.45 & 404.51 \\
\hline $\mathrm{P}_{4} \mathrm{XP}_{5}$ & 11.55 & 16.29 & 17.15 & 17.46 & 29.54 & 292.31 \\
\hline $\mathrm{P}_{4} \mathrm{XP}_{6}$ & 8.92 & 15.10 & 16.13 & 17.31 & 25.31 & 289.77 \\
\hline $\mathrm{P}_{5} \mathrm{XP}_{6}$ & 10.83 & 17.37 & 15.76 & 15.89 & 34.73 & 299.33 \\
\hline BHM5 (check1) & 10.68 & 16.05 & 14.37 & 14.33 & 29.33 & 322.00 \\
\hline BHM7(check2) & 11.38 & 16.23 & 15.20 & 16.57 & 30.29 & 316.00 \\
\hline BHM9(check3) & 11.21 & 15.83 & 14.71 & 15.30 & 27.25 & 331.00 \\
\hline Mean & 10.02 & 15.60 & 14.67 & 14.68 & 27.96 & 312.81 \\
\hline
\end{tabular}




\section{Mean performance of crosses for different characters}

Eight crosses showed higher yield than overall mean (Table 2a). Two crosses namely $\mathrm{P}_{3} \mathrm{xP}_{6} \& \mathrm{P}_{4} \mathrm{xP}_{5}$ produced higher yield than overall mean and also higher yield than all check varieties. All tested crosses were few days earlier than all checks for days to tasseling, silking \& maturity (Table 2b). Short stature plants were also observed for all crosses than all the three check varieties. So all the tested crosses were early \& dwarf in stature compare to the checks.

Table $2 \mathrm{~b}$. Mean performance of crosses for the characters of maturity and growth parameters

\begin{tabular}{l|c|c|c|c|c}
\hline \multicolumn{1}{c|}{ Cross } & $\begin{array}{c}\text { Days to } \\
\text { tasseling }\end{array}$ & $\begin{array}{c}\text { Days to } \\
\text { silking }\end{array}$ & $\begin{array}{c}\text { Days to } \\
\text { maturity }\end{array}$ & $\begin{array}{c}\text { Plant height } \\
(\mathrm{cm})\end{array}$ & $\begin{array}{c}\text { Ear height } \\
(\mathrm{cm})\end{array}$ \\
\hline $\mathrm{P}_{1} \mathrm{XP}_{2}$ & 88.33 & 92.67 & 140.00 & 177.33 & 102.67 \\
$\mathrm{P}_{1} \mathrm{XP}_{3}$ & 88.00 & 92.00 & 143.00 & 198.67 & 115.33 \\
$\mathrm{P}_{1} \mathrm{XP}_{4}$ & 87.33 & 92.00 & 143.67 & 185.00 & 102.00 \\
$\mathrm{P}_{1} \mathrm{XP}_{5}$ & 86.33 & 91.33 & 144.33 & 190.67 & 107.67 \\
$\mathrm{P}_{1} \mathrm{XP}_{6}$ & 88.00 & 93.00 & 148.33 & 143.33 & 95.67 \\
$\mathrm{P}_{2} \mathrm{XP}_{3}$ & 90.00 & 97.00 & 140.67 & 166.00 & 82.33 \\
$\mathrm{P}_{2} \mathrm{XP}_{4}$ & 88.33 & 93.67 & 140.00 & 177.33 & 96.67 \\
$\mathrm{P}_{2} \mathrm{XP}_{5}$ & 85.33 & 89.67 & 142.67 & 191.33 & 103.33 \\
$\mathrm{P}_{2} \mathrm{XP}_{6}$ & 89.67 & 93.67 & 146.33 & 200.00 & 111.67 \\
$\mathrm{P}_{3} \mathrm{XP}_{4}$ & 88.67 & 92.67 & 140.00 & 194.67 & 112.33 \\
$\mathrm{P}_{3} \mathrm{XP}_{5}$ & 92.00 & 92.67 & 145.00 & 198.67 & 107.00 \\
$\mathrm{P}_{3} \mathrm{XP}_{6}$ & 91.33 & 94.67 & 145.33 & 196.67 & 105.00 \\
$\mathrm{P}_{4} \mathrm{XP}_{5}$ & 88.67 & 92.67 & 145.33 & 186.33 & 101.33 \\
$\mathrm{P}_{4} \mathrm{XP}_{6}$ & 89.67 & 94.33 & 143.67 & 166.33 & 89.33 \\
$\mathrm{P}_{5} \mathrm{XP}_{6}$ & 87.67 & 92.67 & 143.67 & 207.67 & 107.67 \\
$\mathrm{BHM}_{4}$ (check1) & 96.33 & 99.67 & 147.33 & 214.00 & 125.00 \\
$\mathrm{BHM}_{\text {(check2) }}$ & 93.67 & 97.67 & 146.67 & 225.00 & 150.00 \\
$\mathrm{BHM}_{4}$ (check3) & 96.33 & 100.00 & 149.67 & 241.33 & 144.67 \\
Mean & 89.76 & 94.00 & 144.09 & 192.24 & 108.70 \\
\hline
\end{tabular}

\section{General combining ability (GCA) effects}

The GCA effects of the parents for different characters are presented in Tables $3 \mathrm{a}$ and $3 \mathrm{~b}$. A wide range of variability for GCA effects were observed among the parents for different traits. The GCA effects are important indicators of the values of inbreds in hybrid combinations. The parents $\mathrm{P}_{5}$ showed highly significant positive GCA effect for grain yield. In addition to grain yield, $\mathrm{P}_{5}$ had 
highly significant positive GCA for cob length, cob girth, number of grain rows/ear, number of grains/row. The Parent $\mathrm{P}_{4}$ was good general combiner for cob girth and number of grain rows/ear. The Parent $\mathrm{P}_{6}$ was found good general combiner for cob length, cob girth, no. of grain rows/ear and thousand grain weight. So, parent $\mathrm{P}_{4}, \mathrm{P}_{5}$ and $\mathrm{P}_{6}$ could be used to develop high yielding maize hybrids. Alam et al. (2008) and Amiruzzaman (2010) also observed similar phenomenon in maize.

Table 3a. General combining ability effects for yield and yield components in 6x6 diallel cross

\begin{tabular}{l|c|c|c|c|c|c}
\hline Parent & Yield (t/ha) & $\begin{array}{c}\text { Cob length } \\
(\mathrm{cm})\end{array}$ & $\begin{array}{c}\text { Cob girth } \\
(\mathrm{cm})\end{array}$ & $\begin{array}{c}\text { No. of grain } \\
\text { rows/ear }\end{array}$ & $\begin{array}{c}\text { No.of } \\
\text { grains/row }\end{array}$ & TGW (g) \\
\hline $\mathrm{P}_{1}$ & $-0.58^{*}$ & $-0.86^{* *}$ & -0.07 & $-0.66^{* *}$ & 0.63 & $-6.44^{*}$ \\
$\mathrm{P}_{2}$ & $-1.01^{* *}$ & $-0.75^{* *}$ & $-1.44^{* *}$ & $-2.38^{* *}$ & $-2.75^{* *}$ & $-7.74^{*}$ \\
$\mathrm{P}_{3}$ & 0.24 & 0.27 & $-0.97^{* *}$ & $-1.10^{* *}$ & $-1.14^{* *}$ & $28.05^{* *}$ \\
$\mathrm{P}_{4}$ & -0.01 & 0.04 & $0.59^{* *}$ & $1.17^{* *}$ & $-0.86^{*}$ & $-10.37^{* *}$ \\
$\mathrm{P}_{5}$ & $1.36^{* *}$ & $0.87^{* *}$ & $1.36^{* *}$ & $2.28^{* *}$ & $3.87^{* *}$ & $-15.82^{* *}$ \\
$\mathrm{P}_{6}$ & 0.01 & $0.42^{*}$ & $0.52^{*}$ & $0.69^{* *}$ & 0.24 & $12.32^{* *}$ \\
\hline $\mathrm{SE}(\mathrm{gi})$ & 0.16 & 0.16 & 0.13 & 0.13 & 0.28 & 2.28 \\
\hline LSD $_{(0.05)}$ & 0.41 & 0.41 & 0.34 & 0.32 & 0.72 & 5.86 \\
\hline LSD $_{(0.01)}$ & 0.65 & 0.65 & 0.54 & 0.50 & 1.13 & 9.19 \\
\hline
\end{tabular}

*** indicate significant at $5 \%$ and $1 \%$ levels, respectively, TGW= Thousand grain weight.

Table 3b. General combining ability effects for maturity and growth parameters in $6 \times 6$ diallel cross.

\begin{tabular}{l|c|c|c|c|c}
\hline Parent & Days to tasseling & $\begin{array}{c}\text { Days to } \\
\text { silking }\end{array}$ & $\begin{array}{c}\text { Days to } \\
\text { maturity }\end{array}$ & $\begin{array}{c}\text { Plant height } \\
(\mathrm{cm})\end{array}$ & $\begin{array}{c}\text { Ear height } \\
(\mathrm{cm})\end{array}$ \\
\hline $\mathrm{P}_{1}$ & $-1.28^{*}$ & $-0.97^{*}$ & 0.50 & $-7.92^{* *}$ & 2.50 \\
$\mathrm{P}_{2}$ & -0.36 & 0.44 & $-1.92^{*}$ & $-3.67^{*}$ & $-4.17^{*}$ \\
$\mathrm{P}_{3}$ & $1.72^{*}$ & $1.03^{* *}$ & -0.83 & $7.00^{* *}$ & 2.17 \\
$\mathrm{P}_{4}$ & -0.11 & 0.11 & -1.17 & $-4.25^{*}$ & -2.92 \\
$\mathrm{P}_{5}$ & -0.78 & $-1.47^{* *}$ & 0.92 & $12.00^{* *}$ & $3.42^{*}$ \\
$\mathrm{P}_{6}$ & 0.81 & 0.86 & 2.5 & $-3.17^{*}$ & -1.00 \\
\hline SE(gi) & 0.47 & 0.25 & 0.50 & 1.22 & 1.24 \\
\hline $\operatorname{LSD}_{(0.05)}$ & 1.21 & 0.64 & 1.29 & 3.14 & 3.19 \\
\hline $\operatorname{LSD}_{(0.01)}$ & 1.90 & 1.00 & 2.01 & 4.92 & 4.50 \\
\hline
\end{tabular}

*,** indicate significant at $5 \%$ and $1 \%$ levels, respectively. 
For maturity and growth parameters significant negative GCA effect is desirable for dwarf and earliness in plant. The parent $\mathrm{P}_{1}$ had significant negative GCA effect was seen for days to tasseling, days to silking and plant height.The parent $\mathrm{P}_{2}$ had significant negative GCA effect for days to maturity, plant height and ear height. So, the parent $\mathrm{P}_{1} \& \mathrm{P}_{2}$ could be used to develop early maturing dwarf hybrid. Das and Islam (1994), Hussain et al. (2003) and Banik (2006) also found some inbred lines with short plant type in their studies.

\section{Specific combining ability effects}

The specific combing ability effects for different characters are presented in Table $4 \mathrm{a}$ and $4 \mathrm{~b}$. For yield and yield components, significant positive SCA effect is desirable. Four crosses $\left(\mathrm{P}_{1} \mathrm{x} \mathrm{P}_{2}, \mathrm{P}_{2} \mathrm{x} \mathrm{P}_{6}, \mathrm{P}_{3} \times \mathrm{P}_{4}\right.$ and $\left.\mathrm{P}_{3} \times \mathrm{P}_{6}\right)$ exhibited significant positive SCA effect for grain yield involving average $\mathrm{x}$ average, average $\mathrm{x}$ low and low $\mathrm{x}$ low general combining parents . The cross $\mathrm{P}_{3} \mathrm{xP}_{6}$ involved average $\mathrm{x}$ average general combiner, exhibited the second highest significant positive SCA effects along with the second highest mean value for yield. Amiruzzaman et al. (2013) and Ahmed (2013) also reported significant SCA effects in some of the crosses involving the parents of average $\mathrm{x}$ average , average $\mathrm{x}$ low and low $\mathrm{x}$ low general combiners for grain yield in maize. The highest yielding hybrid $\left(\mathrm{P}_{4} \times \mathrm{P}_{5}\right)$ could not show significant SCA value. These results showed that high general combining parent $\left(\mathrm{P}_{5}\right)$ could not show high SCA effects in hybrid combinations. Similar findings were also reported by lvy and Hawlader (2000) in maize. On the contrary, Paul and Duara (1991) reported that parents with high GCA always produce hybrids with high estimates of SCA. The cross $\mathrm{P}_{1} \mathrm{xP}_{6}, \mathrm{P}_{2} \mathrm{xP}_{3}$, and $\mathrm{P}_{4} \mathrm{xP}_{6}$ showed significant negative SCA effects along with their low/average GCA value for grain yield. Hoque et al. (2008) and Amiruzzaman et al. (2013) also observed similar results in some of crosses in their study in the same crop. These four crosses also showed significant SCA effects in some yield components. Significant positive SCA effects were observed in five crosses $\left(\mathrm{P}_{1} \times \mathrm{P}_{2}, \mathrm{P}_{1} \times \mathrm{P}_{3}, \mathrm{P}_{1} \times \mathrm{P}_{5}, \mathrm{P}_{3} \times \mathrm{P}_{6}\right.$ and $\left.\mathrm{P}_{4} \times \mathrm{P}_{5}\right)$ for cob girth, five crosses $\left(\mathrm{P}_{1} \times \mathrm{P}_{5}, \mathrm{P}_{2} \times \mathrm{P}_{4}, \mathrm{P}_{2} \times \mathrm{P}_{6}, \mathrm{P}_{3} \times \mathrm{P}_{5}\right.$ and $\left.\mathrm{P}_{4} \times \mathrm{P}_{6}\right)$ for number of grain rows/ear, six crosses $\left(\mathrm{P}_{1} \times \mathrm{P}_{2}, \mathrm{P}_{1} \times \mathrm{P}_{3}, \mathrm{P}_{2} \times \mathrm{P}_{4}, \mathrm{P}_{3} \times \mathrm{P}_{4}, \mathrm{P}_{3} \times \mathrm{P}_{6}\right.$ and $\left.\mathrm{P}_{5} \times \mathrm{P}_{6}\right)$ for number of grains/row and six crosses $\left(\mathrm{P}_{1} \times \mathrm{P}_{2}, \mathrm{P}_{1} \times \mathrm{P}_{3}, \mathrm{P}_{1} \times \mathrm{P}_{5}, \mathrm{P}_{2} \times \mathrm{P}_{4} \mathrm{P}_{2} \times \mathrm{P}_{6}\right.$, and $\mathrm{P}_{3} \times \mathrm{P}_{6}$ ) for thousand grain weight involving high, average and low general combining parents. Uddin et al. (2006) and Ahmed et al. (2008) also observed significant positive SCA effects for some crosses for the mentioned characters.

For maturity and growth parameters, significant negative SCA effect is desirable for dwarfness and earliness in plant. Significant negative SCA effect was observed in one cross $\left(\mathrm{P}_{2} \mathrm{x} \mathrm{P}_{5}\right)$ for days to tasseling, three crosses $\left(\mathrm{P}_{1} \mathrm{x} \mathrm{P}_{3}, \mathrm{P}_{2} \mathrm{x} \mathrm{P}_{5}\right.$ and $\left.\mathrm{P}_{3} \times \mathrm{P}_{4}\right)$ in days to silking and two crosses $\left(\mathrm{P}_{1} \times \mathrm{P}_{2}\right.$ and $\left.\mathrm{P}_{5} \times \mathrm{P}_{6}\right)$ for days to maturity indicating earliness in flowering. These crosses involved high $\mathrm{x}$ average, 
high $\mathrm{x}$ low, average $\mathrm{x}$ average and average $\mathrm{x}$ low general combining parents which is in accordance with Uddin et al. (2006) and Ahmed (2013). Significant negative SCA effect was observed in five crosses $\left(\mathrm{P}_{1} \mathrm{x} \mathrm{P}_{6}, \mathrm{P}_{2} \mathrm{x} \mathrm{P}_{3}, \mathrm{P}_{3} \mathrm{x} \mathrm{P}_{5}, \mathrm{P}_{4} \times \mathrm{P}_{5}\right.$ and $\mathrm{P}_{4} \times \mathrm{P}_{6}$ ) for plant height indicating dwarfness of the hybrids involved high $\mathrm{x}$ high, high $\mathrm{x}$ low, average $\mathrm{x}$ average and low $\mathrm{x}$ low general combining parents. Significant and negative SCA effect was observed in 3 crosses $\left(\mathrm{P}_{1} \mathrm{x} \mathrm{P}_{6}, \mathrm{P}_{2} \mathrm{x} \mathrm{P}_{3}\right.$ and $\mathrm{P}_{4} \mathrm{x} \mathrm{P}_{6}$ ) for ear height indicating lower ear placement involved average $\mathrm{x}$ average and average $\mathrm{x}$ low general combining parents. Ahmed (2013) also observed significant and negative SCA effects involved high $\mathrm{x}$ high, high $\mathrm{x}$ average, high $\mathrm{x}$ low and low $\mathrm{x}$ low general combining parents in his study for plant and ear height.

Table- 4a. Specific combining ability (SCA) effects for different characters in 6x6 diallel cross for yield and yield contributing characters

\begin{tabular}{|c|c|c|c|c|c|c|}
\hline Crosses & Yield (t/ha) & Cob length & Cob girth $(\mathrm{cm})$ & $\begin{array}{c}\text { No. of grain } \\
\text { rows/ ear }\end{array}$ & $\begin{array}{c}\text { No. of } \\
\text { grains/ row }\end{array}$ & $\begin{array}{l}\mathrm{TGW} \\
(\mathrm{g})\end{array}$ \\
\hline $\mathrm{P}_{1} \times \mathrm{P}_{2}$ & $1.05^{* *} *$ & 0.95 & $0.71 *$ & -0.36 & $2.05 * *$ & $26.95^{* *}$ \\
\hline $\mathrm{P}_{1} \mathrm{xP}_{3}$ & 0.70 & 1.96 & $0.92 * *$ & 0.40 & $1.81 * *$ & $8.91 *$ \\
\hline $\mathrm{P}_{1} \times \mathrm{P}_{4}$ & -0.47 & -0.84 & $-1.05^{* *}$ & -0.20 & -0.86 & $-8.88 *$ \\
\hline $\mathrm{P}_{1} \times \mathrm{P}_{5}$ & 0.49 & -0.79 & $0.62 *$ & $0.66^{*}$ & -0.46 & $13.91 * *$ \\
\hline $\mathrm{P}_{1} \times \mathrm{P}_{6}$ & $-1.77 * *$ & -1.28 & $-1.19 * *$ & $-0.50 *$ & $-2.54 * *$ & $-40.89 * *$ \\
\hline $\mathrm{P}_{2} \mathrm{XP}_{3}$ & $-2.58 * *$ & -3.34 & $-1.50 * *$ & $-1.25^{* *}$ & $-4.10 * *$ & $-59.03 * *$ \\
\hline $\mathrm{P}_{2} \mathrm{xP}_{4}$ & 0.22 & 0.71 & 0.16 & $0.56^{*}$ & $1.26^{*}$ & $21.73 * *$ \\
\hline $\mathrm{P}_{2} \mathrm{XP}_{5}$ & -0.22 & 0.31 & 0.12 & -0.12 & 0.84 & -8.07 \\
\hline $\mathrm{P}_{2} \mathrm{xP}_{6}$ & $1.53 * *$ & 1.38 & 0.51 & $1.17 * *$ & -0.05 & $18.42 * *$ \\
\hline $\mathrm{P}_{3} \times \mathrm{P}_{4}$ & $0.74 *$ & 1.13 & -0.02 & $-0.76 * *$ & $2.69 * *$ & 2.37 \\
\hline $\mathrm{P}_{3} \mathrm{XP}_{5}$ & -0.33 & 0.05 & -0.50 & $1.59 * *$ & $-1.99 * *$ & -5.62 \\
\hline $\mathrm{P}_{3} \mathrm{xP}_{6}$ & $1.47 * *$ & 0.21 & $1.10 * *$ & 0.01 & $1.58 * *$ & $53.36 * *$ \\
\hline $\mathrm{P}_{4} \times \mathrm{P}_{5}$ & 0.40 & -0.13 & $0.54^{*}$ & $-0.52 *$ & $-1.24 *$ & 7.72 \\
\hline $\mathrm{P}_{4} \times \mathrm{P}_{6}$ & $-0.89 * *$ & -0.87 & 0.36 & $0.92 * *$ & $-1.84 * *$ & $-22.95 * *$ \\
\hline $\mathrm{P}_{5} \mathrm{XP}_{6}$ & -0.34 & 0.56 & $-0.78 * *$ & $-1.61 * *$ & $2.85^{* * *}$ & -7.95 \\
\hline $\mathrm{SE}(\mathrm{ij})$ & 0.27 & 0.26 & 0.23 & 0.21 & 0.47 & 3.86 \\
\hline $\operatorname{LSD}_{(0.05)}$ & 0.71 & 0.60 & 0.52 & 0.48 & 1.06 & 8.73 \\
\hline $\operatorname{LSD}_{(0.01)}$ & 0.82 & 0.86 & 0.75 & 0.69 & 1.53 & 12.54 \\
\hline
\end{tabular}

$*, * *$ indicate significant at $5 \%$ and $1 \%$ level, respectively; $\mathrm{TGW}=$ Thousand grain weight. 
Table 4b. Specific combining ability (SCA) effects for different characters in $6 \times 6$ diallel cross for maturity and growth parameters

\begin{tabular}{|c|c|c|c|c|c|}
\hline Crosses & Days to tasseling & Days to silking & Days to maturity & $\begin{array}{c}\text { Plant height } \\
(\mathrm{cm})\end{array}$ & $\begin{array}{c}\text { Ear height } \\
(\mathrm{cm})\end{array}$ \\
\hline $\mathrm{P}_{1} \times \mathrm{P}_{2}$ & 1.35 & 0.22 & $-2.05^{*}$ & 3.58 & 1.67 \\
\hline $\mathrm{P}_{1} \times \mathrm{P}_{3}$ & -1.07 & $-1.03^{*}$ & -0.13 & $14.25 * *$ & $8.00 * *$ \\
\hline $\mathrm{P}_{1} \times \mathrm{PP}_{4}$ & 0.10 & -0.12 & 0.87 & $11.83 * *$ & -0.25 \\
\hline $\mathrm{P}_{1} \times \mathrm{P}_{5}$ & -0.23 & 0.80 & -0.55 & 1.25 & -0.92 \\
\hline $\mathrm{P}_{1} \times \mathrm{P}_{6}$ & -0.15 & 0.13 & 1.87 & $-30.92 * *$ & $-8.50 * *$ \\
\hline $\mathrm{P}_{2} \mathrm{XP}_{3}$ & 0.02 & $2.55^{* *}$ & -0.05 & $-22.67 * *$ & $-18.33^{* *}$ \\
\hline $\mathrm{P}_{2} \mathrm{XP}_{4}$ & 0.18 & 0.13 & -0.38 & -0.08 & 1.08 \\
\hline $\mathrm{P}_{2} \mathrm{XP}_{5}$ & $-2.15^{*}$ & $-2.28 * *$ & 0.20 & -2.33 & 1.42 \\
\hline $\mathrm{P}_{2} \mathrm{xP}_{6}$ & 0.60 & -0.62 & $2.28 *$ & $21.50 * *$ & $14.17 * *$ \\
\hline $\mathrm{P}_{3} \mathrm{XP}_{4}$ & -1.57 & $-1.45^{* *}$ & -1.47 & $6.58 *$ & $10.42 * *$ \\
\hline $\mathrm{P}_{3} \mathrm{XP}_{5}$ & $2.43 *$ & 0.13 & 1.45 & $-5.67 *$ & -1.25 \\
\hline $\mathrm{P}_{3} \mathrm{XP}_{6}$ & 0.18 & -0.20 & 0.20 & $7.50 * *$ & 1.17 \\
\hline $\mathrm{P}_{4} \times \mathrm{P}_{5}$ & 0.93 & $1.05^{*}$ & $2.12 *$ & $-6.75^{*}$ & -1.83 \\
\hline $\mathrm{P}_{4} \times \mathrm{PP}_{6}$ & 0.35 & 0.38 & -1.13 & $-11.58 * *$ & $-9.42 * *$ \\
\hline $\mathrm{P}_{5} \mathrm{xP}_{6}$ & -0.98 & 0.30 & $-3.22 * *$ & $13.50 * *$ & 2.58 \\
\hline SE(ij) & 0.80 & 0.43 & 0.85 & 2.08 & 2.11 \\
\hline $\operatorname{LSD}_{(0.05)}$ & 1.81 & 0.97 & 1.92 & 4.70 & 4.77 \\
\hline $\operatorname{LSD}_{(0.01)}$ & 2.60 & 1.40 & 2.76 & 6.76 & 6.86 \\
\hline
\end{tabular}

$*, * *$ indicate significant at $5 \%$ and $1 \%$ level, respectively.

\section{Heterosis}

The estimates of standard heterosis for different characters of 15 single cross maize hybrids is presented in the Tables $5 \mathrm{a}$ and $5 \mathrm{~b}$. The magnitude of heterosis varied widely among crosses for different characters from cross to cross for the same character.

For grain yield, only two crosses viz. $\mathrm{P}_{3} \mathrm{xP}_{6}$ and $\mathrm{P}_{4} \mathrm{xP}_{5}$ showed significant positive heterosis $7.93 \%$ and $8.18 \%$ respectively over check BHM 5.These two crosses also produced numerically higher yield than other two check variety BHM $7 \&$ BHM 9. Rest of the characters were compared with the highest yielding check BHM 7 to calculate heterosis. The cross $\mathrm{P}_{3} \mathrm{XP}_{6}$ showed significant positive heterosis $(28.01 \%)$ for thousand grain weight also. The cross $\mathrm{P}_{4} \mathrm{XP}_{5}$ showed significant positive heterosis $(12.85 \%)$ for cob girth also. Significant positive heterosis was observed in one cross $\left(\mathrm{P}_{5} \mathrm{XP}_{6}\right)$ for cob length, 3 crosses $\left(\mathrm{P}_{1} \mathrm{XP}_{5}\right.$, 
$\left.\mathrm{P}_{4} \mathrm{XP}_{5}, \mathrm{P}_{4} \mathrm{XP}_{6}\right)$ for cob girth, one cross $\left(\mathrm{P}_{5} \mathrm{XP}_{6}\right)$ for number of grains/row and 2 crosses $\left(\mathrm{P}_{1} \mathrm{XP}_{3}, \mathrm{P}_{3} \mathrm{XP}_{6}\right)$ for thousand grain weight (TGW). Amiruzzaman et al. (2013) found highest $9.71 \%$ heterosis for grain yield than check variety in maize. Appreciable percentage of heterosis for grain yield in maize was also reported by Roy et al.(1998) and Uddin et al. (2006).

Table 5a. Percent heterosis over BHM-7 for yield and yield contributing characters

\begin{tabular}{|c|c|c|c|c|c|c|c|c|}
\hline \multirow[b]{2}{*}{ Crosses } & \multicolumn{3}{|c|}{ Yield (t/ha) Over 3 check variety } & \multirow{2}{*}{$\begin{array}{l}\text { Cob } \\
\text { length } \\
(\mathrm{cm})\end{array}$} & \multirow{2}{*}{$\begin{array}{l}\text { Cob girth } \\
(\mathrm{cm})\end{array}$} & \multirow{2}{*}{$\begin{array}{c}\text { No. of } \\
\text { grain } \\
\text { rows/ ear }\end{array}$} & \multirow{2}{*}{$\begin{array}{l}\text { No. of } \\
\text { grains/ } \\
\text { row }\end{array}$} & \multirow[t]{2}{*}{ TGW $(\mathrm{g})$} \\
\hline & BHM 5 & BHM 7 & BHM 9 & & & & & \\
\hline $\mathrm{P}_{1} \mathrm{xP}_{2}$ & $-13.17 * *$ & $-18.51 * *$ & $-17.28 * *$ & $-8.54 * *$ & $-8.84 * *$ & $-32.83 * *$ & $-8.54 *$ & 2.38 \\
\hline $\mathrm{P}_{1} \mathrm{xP}_{3}$ & -4.81 & $-10.66 * *$ & $-9.31 *$ & 3.98 & -4.32 & $-20.50 * *$ & -4.04 & $8.00 *$ \\
\hline $\mathrm{P}_{1} \mathrm{xP}_{4}$ & $-18.16^{* *}$ & $-23.20 * *$ & $-22.03 * *$ & $-14.66 * *$ & $-7.02 *$ & $-10.40 * *$ & $-11.93 * *$ & $-9.78 * *$ \\
\hline $\mathrm{P}_{1} \mathrm{xP}_{5}$ & 3.71 & -2.67 & -1.19 & $-9.22 * *$ & $8.99 * *$ & 1.47 & 5.01 & -4.30 \\
\hline $\mathrm{P}_{1} \mathrm{xP}_{6}$ & $-30.15^{* *}$ & $-34.45 * *$ & $-33.45 * *$ & $-15.05 * *$ & $-8.42 * *$ & $-15.13 * *$ & $-13.83 * *$ & $-12.73 * *$ \\
\hline $\mathrm{P}_{2} \mathrm{xP}_{3}$ & $-39.54 * *$ & $-43.26 * *$ & $-42.40 * *$ & $-27.95 * *$ & $-29.32 * *$ & $-40.80 * *$ & $-34.69 * *$ & $-13.91 * *$ \\
\hline $\mathrm{P}_{2} \mathrm{xP}_{4}$ & $-15.67 * *$ & $-20.86 * *$ & $-19.66 * *$ & -4.44 & $-8.11 * *$ & $-16.21 * *$ & $-16.07 * *$ & -0.51 \\
\hline $\mathrm{P}_{2} \mathrm{xP}_{5}$ & -6.96 & $-12.68 * *$ & $-11.36 * *$ & -1.79 & -3.36 & $-13.58 * *$ & -1.85 & $-11.66^{* *}$ \\
\hline $\mathrm{P}_{2} \mathrm{xP}_{6}$ & -3.18 & $-9.14 *$ & $-7.76^{*}$ & 2.05 & $-6.25^{*}$ & $-15.41 * *$ & $-16.76 * *$ & 5.63 \\
\hline $\mathrm{P}_{3} \mathrm{xP}_{4}$ & 0.91 & -5.30 & -3.87 & 4.46 & $-6.14 *$ & $-16.42 * *$ & -6.06 & 4.69 \\
\hline $\mathrm{P}_{3} \mathrm{xP}_{5}$ & 3.65 & -2.72 & -1.25 & 2.92 & -4.25 & 4.47 & -5.88 & 0.44 \\
\hline $\mathrm{P}_{3} \mathrm{xP}_{6}$ & $7.93 *$ & 1.29 & 2.82 & 1.13 & 0.77 & $-14.69 * *$ & -6.07 & $28.01 * *$ \\
\hline $\mathrm{P}_{4} \mathrm{xP}_{5}$ & $8.18 *$ & 1.52 & 3.06 & 0.39 & $12.85^{* *}$ & 5.39 & -2.47 & $-7.50 *$ \\
\hline $\mathrm{P}_{4} \mathrm{xP}_{6}$ & $-16.51 * *$ & $-21.65 * *$ & $-20.46^{* *}$ & $-6.94 *$ & $6.14 *$ & 4.47 & $-16.43 * *$ & $-8.30 * *$ \\
\hline $\mathrm{P}_{5} \mathrm{xP}_{6}$ & 1.37 & -4.86 & -3.42 & $7.00 *$ & 3.68 & -4.08 & $14.66 * *$ & -5.28 \\
\hline Mean & -8.16 & -13.81 & -12.50 & -4.44 & 3.57 & -12.28 & -8.33 & -1.66 \\
\hline Std error & 3.61 & 3.39 & 3.44 & 2.44 & 2.54 & 3.45 & 2.89 & 2.78 \\
\hline Minimum & -39.54 & -43.26 & -42.4 & -27.95 & -29.32 & -40.80 & -34.69 & -13.91 \\
\hline Maximum & 8.18 & 1.52 & 3.06 & 7.00 & 12.85 & 5.39 & 14.66 & 28.01 \\
\hline $\mathrm{CD}(0.05)$ & 7.74 & 7.27 & 7.37 & 5.24 & 5.45 & 7.39 & 6.19 & 5.97 \\
\hline $\mathrm{CD}(0.01)$ & 10.75 & 10.09 & 10.24 & 7.28 & 7.56 & 10.26 & 8.60 & 8.28 \\
\hline
\end{tabular}

$*$,** indicate significant at $5 \%$ and $1 \%$ levels, respectively; $\mathrm{TGW}=$ Thousand grain weight.

Significant and negative heterosis was observed for maximum crosses in case of maturity and growth parameters which is desirable for a breeder. Out of 15 crosses all crosses showed significant negative heterosis for days to tasseling wih a range of $-8.90 \%$ to $-1.78 \%$. Fourteen crosses showed significant negative heterosis for days to silking and maturity with the range of $-8.19 \%$ to $-0.69 \%$ and $-4.55 \%$ to $-0.23 \%$, respectively. Roy et al. (1998) and Uddin et al. (2006) also observed significant and negative heterosis in some crosses for days to tasseling 
and silking in their studies. All the crosses showed significant negative heterosis for plant height (-36.30 to 7.70) and ear height (- 45.11 to -23.11$)$ indicating dwarfness of the hybrids. Hoque et al. (2008) and Kadir (2010) also observed significant and negative heterosis in some crosses for plant height and ear height in their studies.

Table 5b.Percent heterosis over BHM-7 for maturity and growth parameters.

\begin{tabular}{|c|c|c|c|c|c|}
\hline $\begin{array}{c}\text { Cross } \\
\text { combination }\end{array}$ & $\begin{array}{l}\text { Days to } \\
\text { tasseling }\end{array}$ & $\begin{array}{l}\text { Days to } \\
\text { silking }\end{array}$ & $\begin{array}{l}\text { Days to } \\
\text { maturity }\end{array}$ & $\begin{array}{c}\text { Plant height } \\
(\mathrm{cm})\end{array}$ & $\begin{array}{l}\text { Ear height } \\
\text { (cm) }\end{array}$ \\
\hline$\overline{P_{1} \times P_{2}}$ & $-5.70 * *$ & $-5.12 * *$ & $-2.50 * *$ & $-21.19 * *$ & $-31.56 * *$ \\
\hline $\mathrm{P}_{1} \mathrm{xP}_{3}$ & $-6.05 * *$ & $-5.81 * *$ & $-2.50 * *$ & $-11.70 * *$ & $-23.11 * *$ \\
\hline $\mathrm{P}_{1} \times \mathrm{P}_{4}$ & $-6.76 * *$ & $-5.81 * *$ & $-2.05^{* *}$ & $-17.78^{* *}$ & $-32.00 * *$ \\
\hline $\mathrm{P}_{1} \mathrm{xP}_{5}$ & $-7.83 * *$ & $-6.49 * *$ & $-1.59 * *$ & $-15.26 * *$ & $-28.22 * *$ \\
\hline $\mathrm{P}_{1} \times \mathrm{P}_{6}$ & $-6.05^{* *}$ & $-4.78 * *$ & -0.46 & $-36.30 * *$ & $-36.22 * *$ \\
\hline $\mathrm{P}_{2} \mathrm{xP}_{3}$ & $-3.92 * *$ & -0.69 & $-4.09 * *$ & $-26.22 * *$ & $-45.11 * *$ \\
\hline $\mathrm{P}_{2} \mathrm{XP}_{4}$ & $-5.70 * *$ & $-4.10 * *$ & $-4.55^{* *}$ & $-21.19 * *$ & $-35.56 * *$ \\
\hline $\mathrm{P}_{2} \times \mathrm{P}_{5}$ & $-8.90 * *$ & $-8.19 * *$ & $-2.73 * *$ & $-14.96^{* *}$ & $-31.11 * *$ \\
\hline $\mathrm{P}_{2} \mathrm{xP}_{6}$ & $-4.27 * *$ & $-4.10 * *$ & -0.23 & $-11.11 * *$ & $-25.56 * *$ \\
\hline $\mathrm{P}_{3} \mathrm{XP}_{4}$ & $-5.34 * *$ & $-5.12 * *$ & $-4.55^{* *}$ & $-13.48 * *$ & $-25.11 * *$ \\
\hline $\mathrm{P}_{3} \times \mathrm{P}_{5}$ & $-1.78 * *$ & $-5.12 * *$ & $-1.14 * *$ & $-11.70 * *$ & $-28.67 * *$ \\
\hline $\mathrm{P}_{3} \times \mathrm{P}_{6}$ & $-2.49 * *$ & $-3.07 * *$ & $-0.91 *$ & $-12.59 * *$ & $-30.00 * *$ \\
\hline $\mathrm{P}_{4} \times \mathrm{P}_{5}$ & $-5.34 * *$ & $-5.12 * *$ & $-0.91 *$ & $-17.19 * *$ & $-32.44 * *$ \\
\hline $\mathrm{P}_{4} \times \mathrm{P}_{6}$ & $-4.27 * *$ & $-3.42 * *$ & $-2.05 * *$ & $-26.07 * *$ & $-40.44 * *$ \\
\hline $\mathrm{P}_{5} \mathrm{xP}_{6}$ & $-6.41 * *$ & $-5.12 * *$ & $-2.05^{* *}$ & $-7.70 * *$ & $-28.22 * *$ \\
\hline Mean & -5.39 & -4.80 & -2.24 & -18.30 & -31.56 \\
\hline Std error & 0.48 & 0.44 & 0.37 & 1.90 & 1.52 \\
\hline Minimum & -8.90 & -8.19 & -4.55 & -36.30 & -45.11 \\
\hline Maximum & -.78 & -0.69 & -0.23 & -7.70 & -23.11 \\
\hline $\mathrm{CD}(0.05)$ & 1.03 & 0.93 & 0.80 & 4.27 & 3.25 \\
\hline $\mathrm{CD}(0.01)$ & 1.42 & 1.29 & 1.12 & 5.93 & 4.52 \\
\hline
\end{tabular}

*,** indicate significant at $5 \%$ and $1 \%$ level, respectively.

\section{Conclusion}

From the study, it may be concluded that the parents $\mathrm{P}_{5} \& \mathrm{P}_{6}$ were good combiner for yield and the parents $\mathrm{P}_{1} \& \mathrm{P}_{2}$ were good combiner for both dwarf and earliness. The two hybrids $\left(\mathrm{P}_{3} \times \mathrm{P}_{6} \& \mathrm{P}_{4} \times \mathrm{P}_{5}\right)$ showed good performance for yield and other desirable characters. However, for confirmation, these two hybrids would be further evaluated in wider agro-ecological zones of Bangladesh. 


\section{Refferences}

Abdel-Moneam M.A., A.N. Attia, M.I. El-Emery and E.A. Fayed. 2009. Combining ability and heterosis for some agronomic traits in crosses of maize. Pakistan J. Biolo. Sci. 12(5): 433-438.

Aguiar, C.G., C.A. Scapim, R.J.B. Pinto, A.T. Amaral Jr, L. Silverio and C.A.B. Andrade. 2004. Analise dialelica de linhagens de milho na safrinha. Ciencia Rural. 34: 1731-1737.

Ahmed,S., F. Khatun, M.S.Uddin, B.R. Banik and N. A. Ivy. 2008. Combining ability and heterosis in maize (Zea mays L.). Bangladesh J. Pl. Breed. Genet. 21(2): 27-32.

Ahmed, S. 2013.Study on genetic diversity in maize (Zea mays L.) inbred lines for the development of hybrids. Ph.D dissertation, Dept. Genetics and Plant Breeding, Bangladesh Agricultural University, Mymensingh.

Alam, A.K.M.M., S. Ahmed, M. Begum and M.K. Sultan. 2008. Heterosis and combining ability for grain yield and its contributing characters in maize. Bangladesh J. Agril. Res. 33(3): 375-379.

Amiruzzaman, M. 2010. Exploitation of hybrid vigor from normal and quality protein maize crosses. Ph.D dissertation, Dept. Genetics and Plant Breeding, Bangladesh Agricultural University, Mymensingh.

Amiruzzaman, M., M.A. Islam., L. Hasan., M. Kadir and M.M. Rohman, 2013. Heterosis and combining ability in a diallel among elite inbred lines of maize (Zea mays L.). Emir. J. Food Agric. 25(2):132-137.

Banik, B. R. 2006. Study of combinig ability of locally developed maize hybrids. Annual Research Report, 2005-2006: Maize and barley improvement, Plant breeding Division, BARI, Joydebpur, Gazipur. Pp. 16-18.

Bhatnagar, S., E.J. Bertran and L.W. Rooney. 2004. Combining abilities of quality protein maize inbreds. Crop Sci. 44: 1997-2005.

Das, U.R. and M.H. Islam. 1994. Combining ability and genetic studies for grain yield and its components in maize (Zea mays L.). Bangladesh J. Pl. Breed. Genet. 7: 41-47.

Hussain, S.A., M. Amiruzzaman and Z. Hossain. 2003. Combining ability estimates in maize. Bangladesh. J. Agril. Res. 28: 435-440.

Hoque, M.M., M. Asaduzzaman, M.M. Rahman, S. Zaman and S.A. Begum. 2008. Genetic divergence in maize (Zea mays L.). Bangladesh J. Agric. 9:145-148.

Ivy, N.A. and M.S. Howlader. 2000. Combining ability in maize. Bangladesh J. Agril. Res. 25: 385-392.

Kadir, M.M. 2010. Development of quality protein maize hybrids and their adaptation in Bangladesh. PhD dissertation, Dept. Genetics \& Plant Breeding, Bangladesh Agricultural University, Mymensingh.

Paul, S.K. and R.K. Duara. 1991. Combining ability studies in maize (Zea mays L.). Intl. J. Tropic. Agric. 9: 250-254. 
Roy, N.C., S.U. Ahmed. S.A. Hussain and M.M. Hoque. 1998. Heterosis and combining ability analysis in maize (Zea mays L.). Bangladesh J. Pl. Breed. Genet. 11: 35-41.

Singh, R.K. and P.K. Singh. 1994. A manual on Genetics and Plant Breeding Experimental Techniques. Kalyani Publishers. Ludiana, New Delhi. Pp. 101-105.

Uddin, S.M., F. Khatun, S. Ahmed, M.R. Ali and S.A. Begum. 2006. Heterosis and combining ability in corn (Zea mays L.). Bangladesh J. Bot. 35: 109-116.

Vacaro, E., J. Fernandes, B. Neto, D.G. Pegoraro, C.N. Nuss and L.H. Conceicao. 2002. Combining ability of twelve maize populations. Pesq. Agropec. Bras. Brasilia. 37: 67-72. 